INTERNATIONAL JOURNAL OF RESEARCHES IN BIOSCIENCES, AGRICULTURE AND TECHNOLOGY (C) VISHWASHANTI MULTIPURPOSE SOCIETY (Global Peace Multipurpose Society) R. No. MH-659/13(N) www.vmsindia.org

\title{
HUMAN IMPACTON URBAN LAKEFUTALA-TELANGKHEDI: A CASE STUDY
}

\author{
K. G. Patil1, V. A. Shende ${ }^{2}$ and K. S. Janbandhu ${ }^{1}$ \\ Institute of Science, R. T. Marg, Nagpur (M.S.) India. \\ ${ }^{2}$ K. Z. S. Science College, Bramhani-Kalmeshwar, Dist- Nagpur (M.S.) India. \\ drkgpatil@gmail.com
}

\begin{abstract}
:
Nagpur is one of the greenest cities in India graced with large reservoirs, wetlands, forestlands, agricultural farms, gardens, landscapes etc. The Futala-Telangkhedilake situated in the West of Nagpur; surrounded by wetlands, farmlands, forests and gardens etc. East and North-East area is used for recreational purpose throughout the year. This area was also used for idol immersion during festival days. South-East region of the lake is covered by slums and used for dump their garbage and drain water directly into the lake. The daily activities of slum population and domesticated animals are responsible for fecal contamination of shoreline of lake. This is expected to accentuate environment-related health risks, like water-washed diseases, vector-borne diseases etc. Most of the Southern and Western region covers catchment area of the lake. This area is highly disturbed by grazers and environment disturbance activities like firewood collection, deforestation etc. which increases surface runoff.
\end{abstract}

Keywords:-Degradation, human activity, water pollution, diseases.

\section{Introduction:}

Growing human population densities, intensified land-use, invasive species, often linked to changes in habitat heterogeneity, increasing habitat fragmentation and limited dispersal capacities are threatening ecosystems world-wide and protected areas are often the only refuge for endangered species. Indeed, the effects of these factors on protected areas can be further amplified by changing climatic conditions (Vos et al, 2008 and Beaumont et al, 2009).

Deforestation, expanding agriculture, illegal fishing and hunting, unplanned tourism, and pollution by pesticides have also caused a progressive deterioration of natural habitats (Alho, 2005; Harris et al., 2005, 2006).

The biome has been impacted by the conversion of natural vegetation by human into agricultural fields and pasture for cattle raising, with alteration and loss of natural habitats and biodiversity.

City of Nagpur is situated in the center of India and covers the area of around 220 sq. Kilometers; situated approximately at $21^{\circ 0} 9^{\prime} 0^{\prime \prime}$ N, 79005'24" E, latitude and longitude respectively. Nagpur is one of the greenest cities in India graced with large reservoirs, wetlands, forestlands, agricultural farms, gardens, landscapes etc. The Futala-Telangkhedilake situated in the West of Nagpur; surrounded by wetlands, farmlands, forests and gardens etc. This article discusseshuman impact on urban lake Futala-Telangkhedi, in order to better understand the biome's natural system, to achieve conservation and sustainable use.

\section{Materials and Methods:}

The present study was carried out from March 2014 to February 2015on every fortnight. Authors were examined and recorded the alteration of Lake Habitat, water quality and pollution caused by human activity. This study is designed to illustrate the changes on FutalaTelangkhediLakeand its environment by human beings.

\section{Observation and Discussion:}

Futala-Telangkhedi lake is the common recreation site of Nagpur, situated at 21009'15.3"N, 79002'35.5”E, latitude and longitude respectively. East and North-East area is used for recreational purpose throughout the year. This area was also used for idol immersion during festival days (Fig. 1 and 4). During these days, shore line area were intensely polluted by idol immersion. After immersion of idols the turbidity of water increases and floating wastes were seen on water. Tons of garbage deposited on the shore line of lake, consisting of biodegradable and non-bio-degradable wastes. Particularly the shore line of water body is polluted by solid and dissolved wastes for months. This adversely affects the population of flora and fauna (Patil et al., 2014; Shende and Patil 2013).

South-East region of the lake is covered by slums. They dump their garbage (Fig. 2) and drain water (Fig. 3) directly into the lake. Some domestic animals like cattles, pigs, dogs, poultry etc. flourish nearby garbage and responsible for zoonosis. The complexities of interactions between environment and host are the vectorborne diseases. Hard ticks (such as the vectors of Lyme disease) feed more frequently and for shorter periods than soft ticks. Hard ticks therefore tend to be much more efficient vectors of human diseases. 
The daily activities of slum population and domesticated animals are responsible for fecal contamination of shoreline of lake (Fig. 1). This is expected to accentuate environment-related health risks, including those from water-washed diseases (diarrhea, cholera, typhoid etc.), vectorborne diseases(malaria and dengue fever)etc.Bacterial infection occurs from contaminated water and pollution of drinking and recreational waters. The occurrence of $E$. Coli, amongst other food poisoning bacteria (Fleury et al., 2006). Warmer, wetter climes, particularly during breeding season, could enable malarial mosquitoes to spread their range and survive longer, leading to increased rates of dengue fever and schistosomiasis (Battacharya et al., 2006).

Most of the Southern and Western region covers catchment area of the lake. This area is highly disturbed by grazers and environment disturbance activities like firewood collection (Fig. 5), deforestation etc. which increases surface runoff. Cattle-ranching direct effects on plant productivity and survival; besides constant loss of biomass to herbivores. Large domestic herbivores affect vegetation, both directly by consuming a large portion of its biomass and also indirectly by being selective in preferred items, compacting the soil, foraging on woody vegetation (browsing) and dispersing seed-propagating species (Alho, 2011).
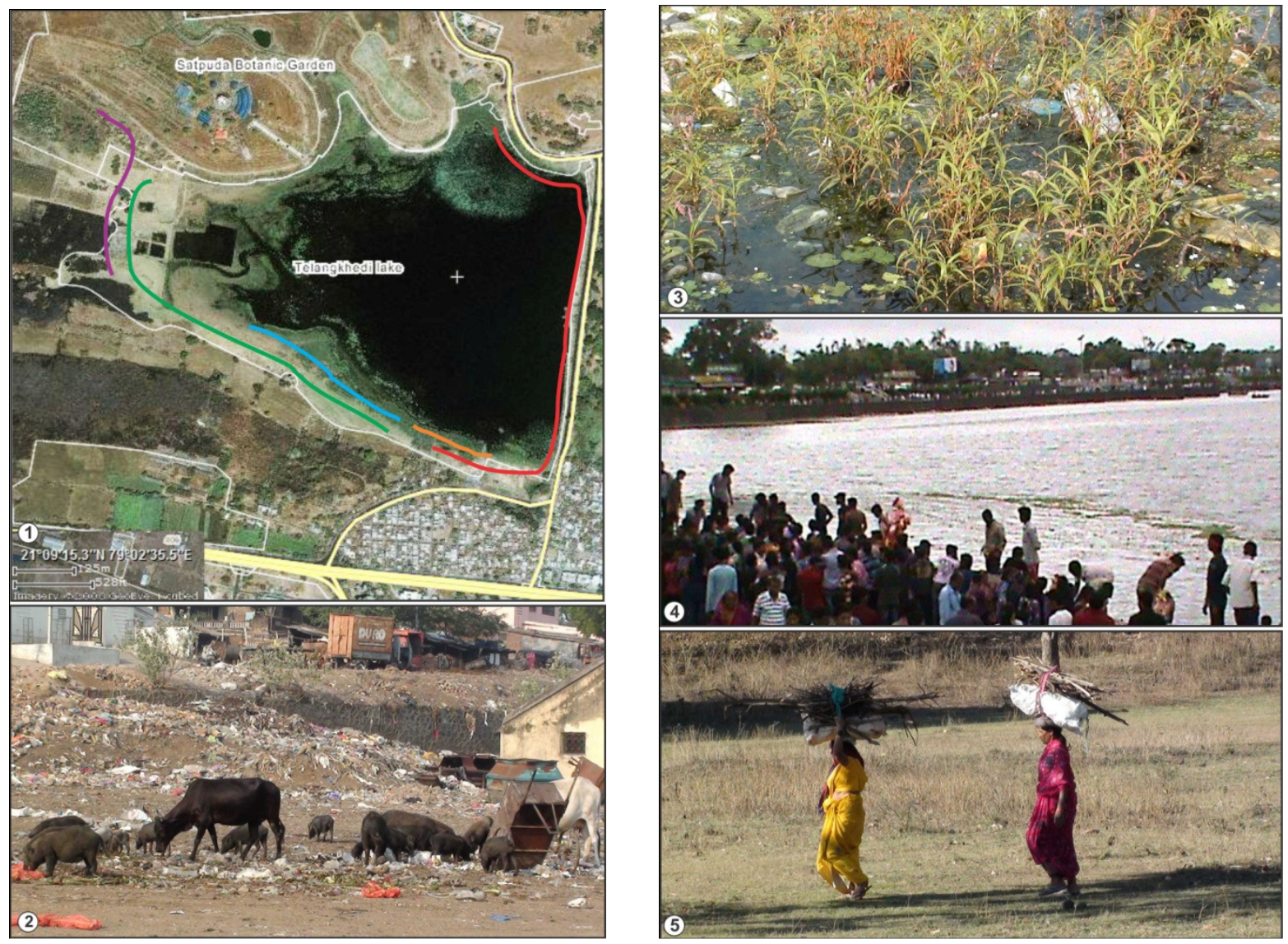

Figure. 1- The Satellite map of Futala-Telangkhedi Lake to show sites of human activities. (CourtesyYahoo map). Red line shows recreation and idol immersion site; Orange line indicates the drain water release and dumping area; Open toilet area shown by Blue line; Grazing zone indicated by Green line and Purple line shows the area of firewood collection.

Figure. 2- Photograph of South-East region showing garbage dumping and activity of domestic animals.

Figure. 3- Photograph of South-East region to shows release of drainage water in the lake.

Figure. 4- Photograph of East and North-East region showing idol immersion sites during festivals.

Figure. 5- Photograph of West region to show carrying materials and firewood.

References:

Alho, C. JR.(2011) Concluding remarks: overall impacts on biodiversity and future perspectives for conservation in the Pantanal biome.Braz. $J$. Biol., vol. 71, no. 1 (suppl.), p. 337-341. 
ALHO, C. JR., (2005)The Pantanal. In: FRASER, LH. and KEDDY, PA., Org. The world's largest wetlands - Ecology and conservation. New York, USA: Cambridge University Press. p. 203271.

Beaumont L.J., Gallagher R.V., Downy P.O., Thuiller W., Leishman M. R. and Hughes L, (2009) Modelling the impact of Hieracium spp. on protected areas in Australia under future climates. Ecography, 32:757-764.

Bhattacharya S., Sharma C., Dhiman R. C. and Mitra A. P. (2006) Climate change and malaria in India, Current Science, 90(3): 369375.

Fleury M. D., Charron D. F., Holt J. D., Allen O. B. and Maarouf A. R.(2006)The role of ambient temperature in food borne disease in Canada using time series methods. Int. J. Biometeorol., 50.

Harris, M. B., Tomas, W. M., Mourão, G. M., Da Silva, C. J., Guimarães, E., Sonoda, F. and

Fachim, E., (2005)Desafios para proteger o Pantanal brasileiro: ameaças e iniciativasemconservação. Megadiversidade, vol. 1 , no. 1 , p. $156-164$.

Harris, M. C., Arcângelo, C., Pinto, E. C. T., Camargo, G., Ramos-Neto, M. B. and Silva, S. M., (2006)Estimativa da perda de cobertura vegetal original naBacia do Alto Paraguai e Pantanal brasileiro: ameaças e perspectivas. Natureza e Conservação, vol. 4, no. 2, p. 50-66.

Patil K. G, Shende V. A. and Janbandhu K. S. (2014) Prelimenary Study of Effects of Idol Immerssion on Futala-Telangkhedi Lake Nagpur, India. International Journal of Researches in Biosciences, Agriculture and Technology 2(2): 408-410.

Shende V.A. and Patil K.G. (2013)Human beings and biodiversity degradation.Int. J. of Life Sciences1(1): 1-8.

Vos C. C., Berry P., Opdam P., Baveco H., Nijhof B., O'Hanley J., Bell C. and Kuipers H. (2008) Adapting landscapes to climate change: examples of climate-proof ecosystem networks and priority adaptation zones. Journal of Applied Ecology, 45:1722-1731. 